\title{
Production of Caupi Beans and Chemical Attributes of a Latosol Under Soil Correction Levels
}

\author{
Jessivaldo R. Galvão ${ }^{1}$, Tiago K. M. Yakuwa ${ }^{1}$, Leonardo B. Araújo ${ }^{1}$, Francisco J. de O. Parise ${ }^{1}$, \\ Rosemiro dos S. Galate ${ }^{1}$, Ilano S. B. do Nascimento ${ }^{1}$, Pedro S. da S. Campos ${ }^{1}$, Ismael de J. M. Viégas ${ }^{1}$, \\ Kalyne P. M. Nascimento ${ }^{2} \&$ Leonardo de A. Oliveira ${ }^{1}$ \\ ${ }^{1}$ Universidade Federal Rural da Amazônia, Belém, Pará, Brazil \\ ${ }^{2}$ Universidade Estadual do Maranhão, Imperatriz, Maranhão, Brazil \\ Correspondence: Jessivaldo R. Galvão, Institute of Agricultural Sciences, Universidade Federal Rural da \\ Amazônia, Soil Department, Tancredo Neves, № 2501, Montese, Belém, Pará, Brazil. Tel: 55-(91)-988-421-133. \\ E-mail: jessi.galvao50@gmail.com
}

Received: July 30, 2018

doi:10.5539/jas.v10n11p436
Accepted: September 3, $2018 \quad$ Online Published: October 15, 2018

URL: https://doi.org/10.5539/jas.v10n11p436

\begin{abstract}
The cowpea [Vigna unguiculata (L.) Walp] represents an important source of income and employment in the northeastern region of Para, also being a valuable source of protein in the diet, especially for the rural population. However, the productivity is low, mainly due to the low fertility of the soils used in the region for the cultivation of this plant. In this context, the correction of the factors responsible for the soil limitations that lead to nutrient deficiency, by means of lime, is of great practical importance for obtaining greater yields of crops grown in acidic soils. The objective was to evaluate the effects of five doses of lime in the production of cowpea beans, BR3-Tracuateua and BR2-Bragança cultivars and chemical attributes of a dystrophic oxisoil, at Tracuateua city. The study was a randomized block designed experimental in a factorial $(5 \times 2)$ with four replications. The terms of the factorial refer to five doses of limestone and two cowpea cultivars. Liming increased $\mathrm{pH}$ and concentrations of phosphorus, calcium and magnesium, reducing the Al concentration and saturation. Lime dosages did not provide significant increases in grain production. The cultivar BR3-Tracuateua was more efficient in all liming levels, producing more than $30 \%$ of grain than the BR-2 Bragança.
\end{abstract}

Keywords: availability of nutrients, dolomitical calcarium, liming, grain production

\section{Introduction}

The cowpea [Vigna unguiculata (L.) Walp.], also known as black-eyed peas and/or macassar beans, is a plant that belongs to the Fabaceae family (subfamily Faboideae). Considered a culture of great economic, social, nutritional and functional, it is a good alternative to increase family incomes in many regions (Bennett et al. 2013).

The state of Para stands out as the fourth national producer of cowpea (Freire Filho, 2011). Its annual average production in the period of 2005-2009 was 513.619 t. In the same period, the Northeast annually produced $426.367 \mathrm{t}$, confirming its superiority over other producing regions. However, it had the lowest average yield (330 $\mathrm{kg} \mathrm{ha}^{-1}$ ) compared to other regions (Freire Filho et al., 2012).

The greater extent croplands used in the North are Oxisols and Argisoils, prevalent in $75 \%$ of Amazon having high acidity, low cation exchange capacity, high phosphorus fixation and low concentrations of exchangeable bases (Junior Vale et al., 2011). Thus, the establishment of rational cropping systems with the adoption of more appropriate technologies that enable improvement of soil conditions, combined with the use of more adapted cultivars in each region of cultivation can leverage the low average productivity values $\left(330 \mathrm{~kg} \mathrm{ha}^{-1}\right)$ currently achieved (Furtado et al., 2012).

In the case of soil acidity correction liming promotes neutralization of $\mathrm{Al}^{3+}, \mathrm{pH}$ elevation and supply $\mathrm{Ca}^{2+}$ and $\mathrm{Mg}^{2+}$, allowing the proliferation of roots with positive effects on shoot growth of plants (Natale et al., 2007).

The objective of this experiment was to study the effects of liming on the chemical properties of a Yellow Oxisol and the productivity of two cultivars of $V$. unguiculata. 


\section{Material and Methods}

\subsection{Research Methodology}

The study was conducted from June to September of 2003, in the Agropecuária Milênio farm, Tracuateua city, mesoregion of the northeastern of Para state, between the geographical coordinates of $00^{\circ} 46^{\prime} 18^{\prime \prime}$ South latitude and $47^{\circ} 10^{\prime} 35^{\prime \prime}$ West longitude of Greenwich. The climate in the region is the Awi type and, according to the National Institute of Meteorology, it is divided into two seasons: rainy from December to May and less rainy from June to November, with an average of $2,500 \mathrm{~mm}$ rainfall, $27.7{ }^{\circ} \mathrm{C}$ of temperature and $84 \%$ of relative humidity per year.

The experiment was established in a randomized block design in a factorial arrangement $(5 \times 2)$, referring to the five levels of liming $\left(0 ; 1 ; 2 ; 3\right.$ and $4 \mathrm{t}$ lime ha $\left.{ }^{-1}\right)$ and two regional cultivars of cowpea (BR2 Bragança and BR3 Tracuateua), with four replications, consisting of 40 experimental units.

\subsection{Soil Sampling}

The samples collected at soil layer 0-0.2 $\mathrm{m}$ from the experimental area, classified as Dystrophic Yellow Latosol sandy texture (Embrapa, 2006), were air-dried and processed in sieve with $2 \mathrm{~mm}$ mesh diameter for chemical and granulometric analysis (Table 1).

\subsection{Soil Characterization}

Table 1. Chemical characteristics and grain size of the Yellow Dystrophic Oxisol before the experiment

\begin{tabular}{|c|c|c|c|c|c|c|c|c|c|c|c|c|c|}
\hline $\mathrm{pH}$ & $\mathrm{P}$ & $\mathrm{K}^{+}$ & $\mathrm{Ca}^{2+}$ & $\mathrm{Mg}^{2+}$ & $\mathrm{Na}^{2+}$ & $\mathrm{Al}^{+3}$ & SB & $\mathrm{T}$ & $\mathrm{m}$ & V & Sand & Silt & Clay \\
\hline $\mathrm{H}_{2} \mathrm{O}$ & $\mathrm{mg} \mathrm{dm}^{-3}$ & ------ & ------ & ---- c & $1_{c} \mathrm{dm}^{-3}$ & ------ & ---- & ---- & ------- & ------- & ------ & $\mathrm{g} \mathrm{dm}^{-3}$ & $-\cdots$ \\
\hline 4.7 & 11.0 & 0.09 & 1.8 & 0.6 & 0.01 & 1.0 & 2.5 & 3.5 & 28.57 & 71.43 & 870 & 50.0 & 90.0 \\
\hline
\end{tabular}

Twenty-five days before planting cultivars BR2 and BR3 Tracuateua Bragança, the application of lime was held and incorporated into the depth of 0 to $0.2 \mathrm{~m}$ by means of two disk harrowings and one disking. The applied correction doses $\left(0 ; 1 ; 2 ; 3\right.$ and $\left.4 \mathrm{t} \mathrm{ha}^{-1}\right)$ corresponded to $0 ; 0.5 ; 1 ; 1.5$ and 2 times the need for liming to neutralize exchangeable aluminum of the soil, calculated in accordance with the recommendations of Cravo et al. (2007).

After liming, seeding cultivars was performed with a $0.50 \mathrm{~m}$ space between rows and eight plants per linear meter. The experimental area of $1.452 \mathrm{~m}^{2}$ was divided into plots measuring $48 \mathrm{~m}^{2}$. In all plots a basic fertilizer was made up of $150 \mathrm{~kg} \mathrm{ha}^{-1} \mathrm{P}_{2} \mathrm{O}_{5}$ in a triple superphosphate form, $120 \mathrm{~kg} \mathrm{ha}^{-1} \mathrm{~K}_{2} \mathrm{O}$ in a potassium chloride form, complemented with a micronutrients fertilizer on the basis of $30 \mathrm{~kg} \mathrm{ha}^{-1}$ FTE BR-12. Plants were harvested 72 days after planting. The beans were adjusted to $13 \%$ of moisture and determined the productivity $\left(\mathrm{kg} \mathrm{ha}^{-1}\right)$. The variables were $\mathrm{pH}$, aluminum saturation, concentration of $\mathrm{Al}, \mathrm{P}, \mathrm{K}, \mathrm{Ca}, \mathrm{Mg}$, sum of bases and grain yield.

\subsection{Statistical Analysis}

The results were submitted to analysis of variance, compared by 5\% SNK test and when relevant, carried regression studies by adjusting the equations according to the data obtained in the treatments.

\section{Results and Discussion}

The $\mathrm{pH}$, aluminum saturation ( $\mathrm{m} \%)$, exchangeable aluminum $(\mathrm{Al})$ and the concentration of phosphorus $(\mathrm{P})$ adjusted to the quadratic regression model. The $\mathrm{pH}$ values were better adjusted to the increasing linear regression model growing significantly with the increase of applied limestone rates (Figure 1a). 

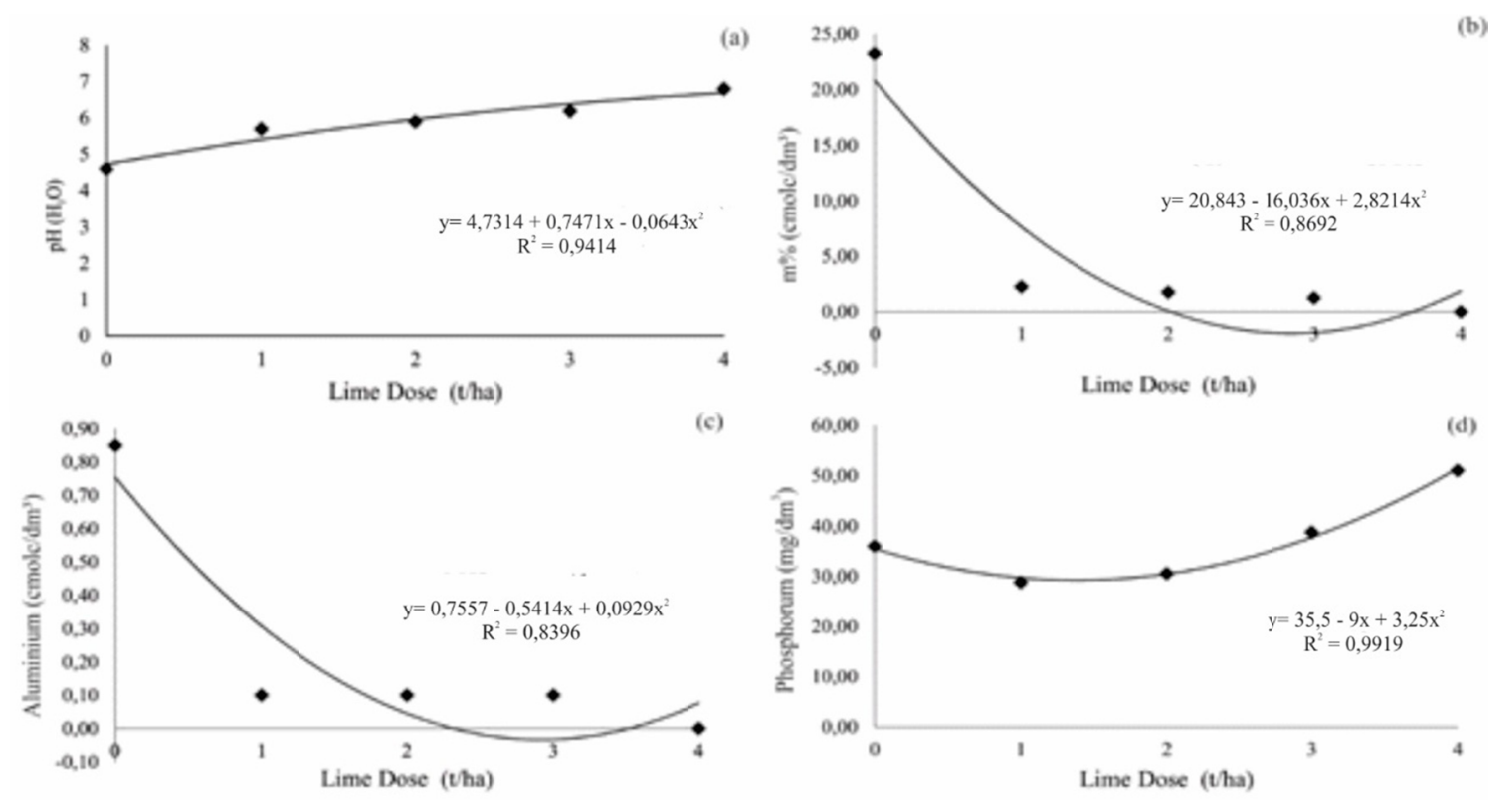

Figure 1. pH (1a), saturation of aluminum (1b), exchangeable aluminum (1c) and phosphorus (1d) values by means of limestone doses applied in a Yellow Oxisol, Tracuateua-PA

The application of $4.5 \mathrm{t} \mathrm{ha}^{-1}$ of lime provided a significant increase in the $\mathrm{pH}$ of a Red Distrophic Oxisol, in Ponta Grossa, PR, Brazil (Caires et al., 2004). The pH affects the competitive ability of the plant, either by limiting the availability of a nutrient or by directly affecting their growth, especially the roots. Results of several studies show the positive effect of liming on increasing soil pH (Araújo et al., 2009; Dos Anjos et al., 2011; Schultz et al., 2011).

The decrease in aluminum saturation (Figure 1b) follow the same behavior pattern observed for the exchangeable $\mathrm{Al}^{+3}$ concentrations (Figure 1c), ranging from $20.6 \%$ to zero at the highest dose of lime. It is observed that the dose of one $\mathrm{tha}^{-1}$ of limestone would be sufficient to reduce the soil exchangeable $\mathrm{Al}$ and the $\mathrm{m} \%$ for non-toxic levels, $0.10 \mathrm{cmol}_{\mathrm{c}} \mathrm{dm}^{-3}$ and $2.25 \%$, respectively, as advocated by Freire Filho et al., (2005). In an experiment conducted in Dystrophic Yellow Latosol in Tracuateua, northeast of Para, the application of one $\mathrm{t} \mathrm{ha}^{-1}$ of lime reduced from $29 \%$ to $6 \%$ of the value of soil aluminum saturation (Cravo et al., 2012).

The aluminum concentration was influenced significantly by lime levels, reaching the complete neutralization at a dose of $4 \mathrm{tha}^{-1}$ of lime. The most obvious symptom of the harmful effect of toxic levels of aluminum is the reduction of root growth, which prevents the plant from obtaining water and nutrients in depth because of its surface rooting (Miguel et al., 2010; Feitosa et al., 2012). Liming effect results in reducing soil exchangeable aluminum are reported by Alleoni et al. (2005); Caires et al. (2008); Fernandes et al. (2013) and Schultz et al. (2011).

There was significant response at $\mathrm{P}$ available in the soil (Figure 1d), with quadratic effects, according to the limestone doses. The phosphate fertilizers and levels found in the soil may have contributed to this increase of $\mathrm{P}$ concentration. It is noted that the $\mathrm{P}$ values obtained from all treatments were higher than the level considered high $\left(>15 \mathrm{mg} \mathrm{dm}^{-3}\right.$ ) for the culture of cowpea (Cravo et al., 2007). The increase in $\mathrm{pH}$ by liming provides hydrolysis of minerals such as strengite and variscite; releasing ions phosphate in the soil solution, also occurring an increase of negative charges on the surfaces of the soil colloids resulting in an increase of electrostatic repulsion (lower adsorption) between the phosphate and the adsorbent surface, reducing the maximum adsorption capacity of $\mathrm{P}$ in the soil (Novais et al., 2007; Souza et al., 2006). The increase of P availability provided by the use of lime was also observed by Silva et al. (2007) in a Red Distroferric Oxisol.

Lime rates applied caused significant effects of increasing linearly in $\mathrm{Ca}, \mathrm{Mg}$ and sum of bases and quadratically to $\mathrm{K}$ (Figure 2). Probably the limestone was efficient in providing constant $\mathrm{Ca}$ and $\mathrm{Mg}$ of its composition, raising the levels of these nutrients in the soil, results that corroborate to those observed by Araújo et al. (2009); Schultz et al. (2011), and Soratto and Crusciol (2008). 


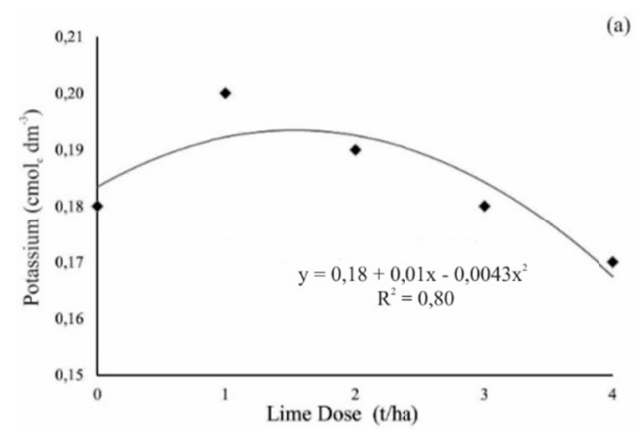

(a)
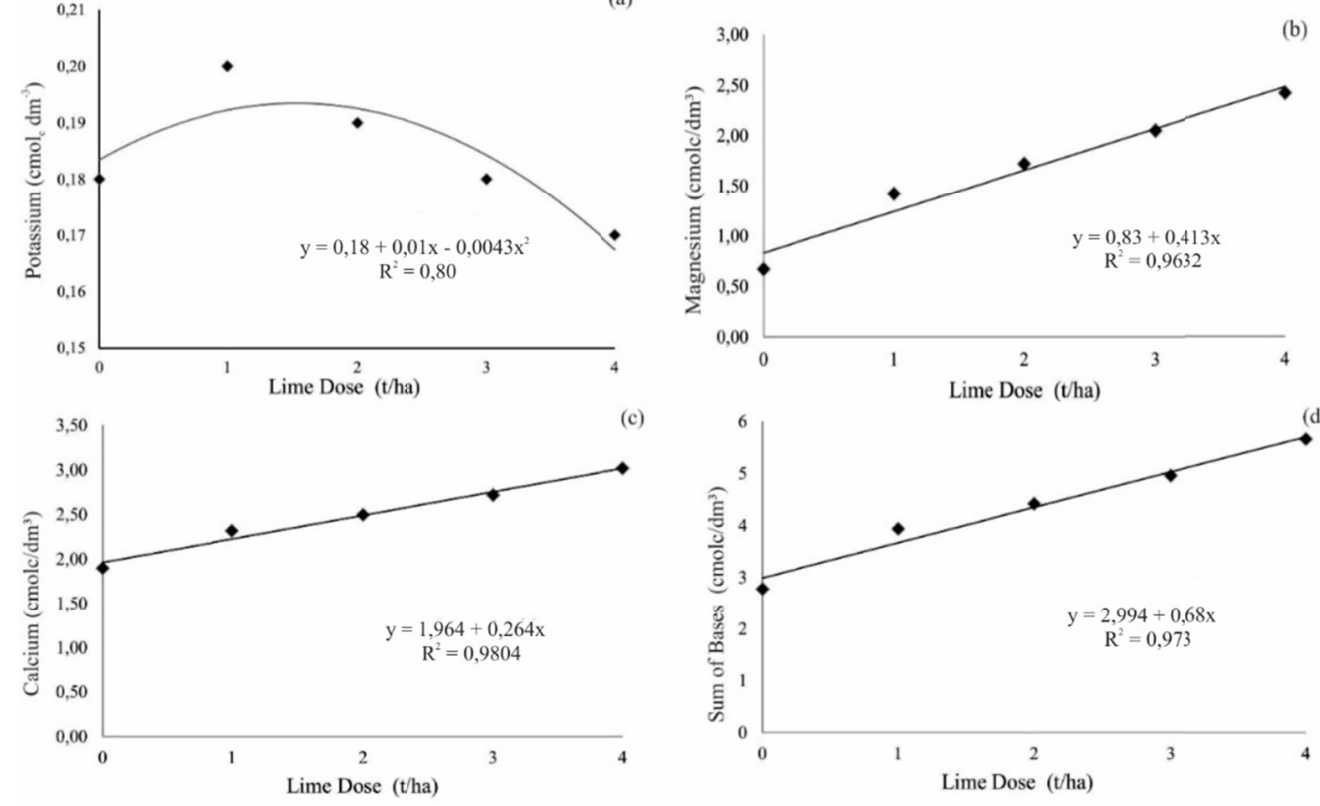

(c)

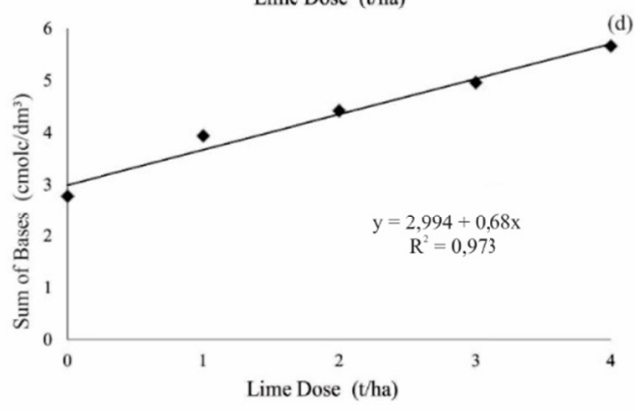

Figure 2. Levels of Potassium (2a), magnesium (2b), calcium (2c) and sum of bases (2d) in function of limestone doses applied in a Yellow Oxisol, Tracuateua-PA

The maximum value of $\mathrm{K}$ was obtained with $0.19 \mathrm{cmolc} \mathrm{dm}^{-3}$ at a dose of $1.5 \mathrm{t} \mathrm{ha}^{-1}$ (Figure 2a). The lack of response in liming in the increase of $\mathrm{K}$ concentration can be attributed to possible effects caused on the ionic balance in the soil and, consequently, on the availability of some nutrients. The greater availability of $\mathrm{Ca}$ and $\mathrm{Mg}$ by liming may have hindered the absorption of $\mathrm{K}$ by cowpea plants. Several studies report that high concentrations of $\mathrm{Ca}$ in the soil solution can affect the absorption of cations such as $\mathrm{K}$ and $\mathrm{Mg}$ and increase the absorption of anions, due to the access of these ions to the absorption sites (Araújo et al., 2009; Caires et al., 2004; Salvador et al., 2011; Silva Junior et al., 2013). The K concentrations obtained in all treatments are considered high level for the criteria of fertilizer recommendation to cowpea (Cravo et al., 2007).

The interaction between liming and cowpea cultivars was significant for grain production, verifying that the quadratic model was best fit for the results (Figure 3). The grain yield differences at each level of liming for both cultivars were less than $5 \%$. It is possible that this lack of response to liming is associated with the fact that the initial content of $\mathrm{Ca}^{+2}+\mathrm{Mg}^{+2}$ presented in the soil $\left(2.40 \mathrm{cmol}_{\mathrm{c}} \mathrm{dm}^{-3}\right)$ was above the level considered suitable for cowpea, which is $2.0 \mathrm{cmolc} \mathrm{dm}^{-3}$ (Freire Filho et al., 2005). In cowpea crops conducted in 2003 and 2004 in a medium texture Oxisol with an initial content of $2.40 \mathrm{cmolc} \mathrm{dm}$ of $\mathrm{Ca}^{+2}+\mathrm{Mg}^{+2}$ in Tracuateua, Pará, there was no significant response for liming, in terms of grain yield (Cravo et al., 2012).

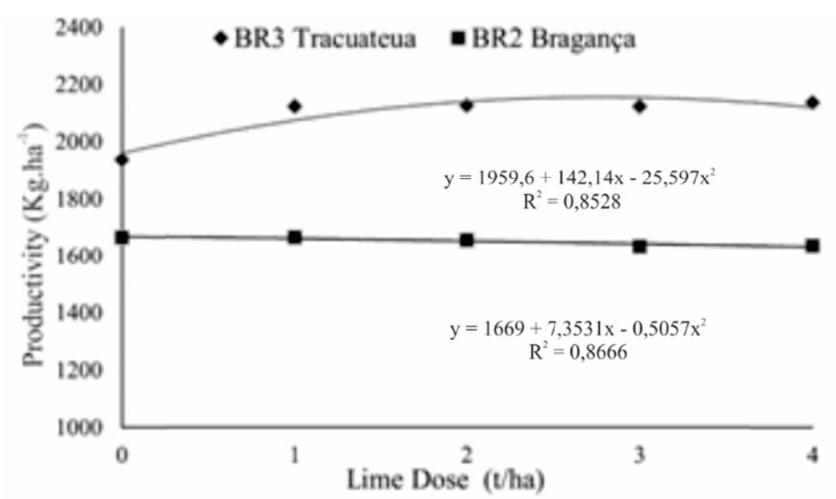

Figure 3. Grain yield $\left(\mathrm{kg} \mathrm{ha}^{-1}\right)$ of cowpea BR3 Tracuateua and BR2 Bragança cultivars in function of lime doses applied in a Yello Oxisoil, Tracuateua-PA 
The highest yield obtained for the BR3 Tracuateua was $2188.36 \mathrm{~kg} \mathrm{ha}^{-1}$ at a dose of $2.66 \mathrm{t} \mathrm{ha}^{-1}$ of lime and $1677.90 \mathrm{~kg} \mathrm{ha}^{-1}$ to $1.80 \mathrm{t} \mathrm{ha}^{-1}$ of lime to the BR2 Bragança. It is noted that the cultivar BR3 Tracuateua required a higher amount of limestone for maximum productivity, leading one to believe that this cultivar is little tolerant to high acidity. In both cases, the achieved productivity was higher than the regional average of $1,000 \mathrm{~kg} \mathrm{ha}^{-1}$ of grains (Cravo et al., 2012).

In a study conducted by Cravo et al. (2012) by testing increasing doses of lime in four cowpea varieties, including the BR2 Bragança and BR3 Tracuateua, it was observed that the BR3 Tracuateua showed to be more sensitive to soil acidity, similar to the results found in this experiment. Cowpea production increases, after liming, have been demonstrated in several research papers (Novais et al., 2007; Cravo et al., 2012).

\section{Conclusions}

The application of lime in the studied Yellow Oxisoil provides an increase in the levels of available phosphorus, $\mathrm{Ca}^{+2}, \mathrm{Mg}^{+2}, \mathrm{pH}$ and the sum of bases with reduction of $\mathrm{Al}^{+3}$ levels and the percentage of saturation of this element; The culture of cowpea does not respond to liming in yellow oxisoil, with more than $2.4 \mathrm{cmolc} \mathrm{dm}^{-3}$; Productivity found among cowpea cultivars was higher in BR3 Tracuateua.

\section{References}

Alleoni, L. R. F., Cambri, M. A., \& Caires, E. F. (2005). Atributos químicos de um Latossolo de cerrado sob plantio direto, de acordo com doses e formas de aplicação de calcário. Revista Brasileira de Ciência do Solo, 29(6), 923-934. https://doi.org/10.1590/S0100-06832005000600010

Araújo, S. R., Demattê, J. A. M., \& Garbuio, F. J., (2009). Aplicação de calcário com diferentes graus de reatividade: Alterações químicas no solo cultivado com milho. Revista Brasileira de Ciência do Solo, 33(6), 1755-1764. https://doi.org/10.1590/S0100-06832009000600024

Benett, C. G. S., Lima, M. F., Benett, K. S. S., Caione, G., \& Pelloso, M. F. (2013). Formas de aplicação e doses de nitrogênio em cobertura na cultura do feijão-caupi. Revista Agrotecnologia, 4(1), 17-30. https://doi.org/ 10.12971/2179-5959/agrotecnologia.v4n1p17-30

Caires, E. F., kusman, M. T., Barth, G. Garbuio, F. J., \& Padilha, J. M. (2004). Alterações químicas do solo e resposta do milho à calagem e aplicação de gesso. Revista Brasileira de Ciência do Solo, 28(1), 125-136. https://doi.org/10.1590/S0100-06832004000100013

Caires, E. F., Pereira Filho, P. R. S., Zardo Filho, R., \& Feldhaus, I. C. (2008). Soil acidity and aluminium toxicity as affected by surface liming and cover oat residues under a no-till system. Soil Use and Management, 24(3), 302-209. https://doi.org/10.1111/j.1475-2743.2008.00166.x

Cravo, M. S., Viégas, I. J. M., \& Brasil, E. C. (2007). Recomendação de adubação e calagem para o Estado do Pará (1st ed.). Embrapa Amazônia Oriental.

Cravo, M. S., Smyth, T. J., \& Brasil, E. C. (2012). Calagem em Latossolo Amarelo Distrófico da Amazônia e sua influência em atributos químicos do solo e na produtividade de culturas anuais. Revista Brasileira de Ciência do Solo, 36(3), 895-907. https://doi.org/10.1590/S0100-06832012000300020

Dos Anjos, J. L., Sobral, L. F., \& Junior, M. A. L. (2011). Efeito da calagem em atributos químicos do solo e na produção da laranjeira. Revista Brasileira de Engenharia Agrícola e Ambiental, 15(11), 1138-1142. https://doi.org/10.1590/S1415-43662011001100005

EMBRAPA. (2006). Sistema Brasileiro de Classificação de Solos (2nd ed.). Embrapa Solos: Centro Nacional de Pesquisa de Solos.

Feitosa, E. O., Carvalho, C. M. de, Silva, L. L., Carvalho, M. R. G. S., Souza, R. da P. F. de, \& Gomes, A. O. (2012). Crescimento inicial do feijão de corda preto sob diferentes doses de adubação nitrogenada. Revista Brasileira de Agricultura Irrigada, 6(4), 271-282. https://doi.org/10.7127/rbai.v6n400092

Fernandes, A. R., Fonseca, M. R., \& Braz, A. M. S. (2013). Produtividade de feijão caupi em função da calagem e fósforo. Revista Caatinga, 26(4), 54-62.

Freire Filho, F. R. (2011). Feijão-caupi no Brasil: Produção, melhoramento genético, avanços e desafios (1st ed.). Embrapa Meio Norte.

Freire Filho, F. R., Lima, J. A. A., \& Ribeiro, V. Q. (2005). Feijão-Caupi: Avanços tecnológicos (1st ed.). Embrapa Informação Tecnológica. 
Freire Filho, F. R. (2012). Feijão-caupi: Produção, melhoramento genético, avanços e desafios (1st ed.). Embrapa Informação Tecnológica.

Furtado, G. F., Sousa Junior, J. R. de, Sousa. J. R. M. de, Lacerda, R. R. de A., \& Souza, A. S. (2012). Produtividade e uso eficiente da terra no consórcio de mamona com gergelim e feijão-caupi no semiárido paraibano. Revista Verde, 7(2), 156-162.

Miguel, P. S. B., Gomes, F. T., Rocha, W. S. D. da, Martins, C. E., Carvalho, C. A. de, \& Oliveira, A. V. de. (2010). Efeito tóxico do alumínio no crescimento das plantas: Mecanismos de tolerância, sintomas, efeitos fisiológicos, bioquímicos e controles genéticos. CES Revista, 24(1), 13-29.

Natale, W., Prado, R. de M., Rozane, D. E., \& Romualdo, L. M. (2007). Efeitos da calagem na fertilidade do solo e na nutrição e produtividade da goiabeira. Revista Brasileira de Ciência do Solo, 31(1), 1475-1485. https://doi.org/10.1590/S0100-06832007000600024

Salvador, J. T., Carvalho, T. C., \& Lucchesi, L. A. C., (2011). Relações cálcio e magnésio presentes no solo e teores foliares de macronutrientes. Revista Acadêmica: Ciências Agrárias e Ambientais, 9(1), 27-32. https://doi.org/10.7213/cienciaanimal.v9i1.11060

Schultz, N., Loss, A., Pereira, M. G., Beutler, S. J., \& Zonta, E. (2011). Desenvolvimento de feijoeiro comum em amostras de Organossolo com diferentes níveis de calagem. Revista Ciência Agronômica, 42(2), $285-291$. https://doi.org/10.1590/S1806-66902011000200005

Silva, C. A., Rangel, O. J. P., \& Belizário, M. H., (2007). Interação calagem-adubação fosfatada e sua influência nos níveis críticos de $\mathrm{P}$ e crescimento do eucalipto. Scientia Forestalis, 73(1), 63-72.

Silva Júnior, G. B., Cavalcante, Í. H. L., Albano, F. G., \& Osajima, J. A. (2013). Estado nutricional e clorofila foliar do maracujazeiro-amarelo em função de biofertilizantes, calagem e adubação com N e K. Revista Ciência Agronômica, 36(2), 163-173.

Soratto, R. P., \& Crusciol, C. A. C. (2008). Atributos químicos do solo decorrentes da aplicação em superfície de calcário e gesso em sistema plantio direto recém-implantado. Revista Brasileira de Ciência do Solo, 32(2), 675-688. https://doi.org/10.1590/S0100-06832008000200026

Souza, R. F., Faquin, V., Torres, P. R. F., \& Baliza, D. P. (2006). Calagem e adubação orgânica: Influência na adsorção de fósforo em solos. Revista Brasileira de Ciência do Solo, 30(6), 975-983. https://doi.org/ 10.1590/S0100-06832006000600007

Sousa, D. M. G., Miranda, L. N., \& Oliveira, S. A. (2007). Acidez do solo e sua correção. In R. F. Novais, et al. (Eds.), Fertilidade do solo (1st ed., pp. 205-274). Sociedade Brasileira de Ciência do Solo.

Vale Júnior, J. F., Souza, M. I. L. de, Nascimento, P. P. R. R., \& Cruz, D. L. de S. (2011). Solos da Amazônia: Etnopedologia e desenvolvimento sustentável. Revista Agroambiente On-line, 5(2), 158-165. https://doi.org/ 10.18227/1982-8470ragro.v5i2.562

\section{Copyrights}

Copyright for this article is retained by the author(s), with first publication rights granted to the journal.

This is an open-access article distributed under the terms and conditions of the Creative Commons Attribution license (http://creativecommons.org/licenses/by/4.0/). 